
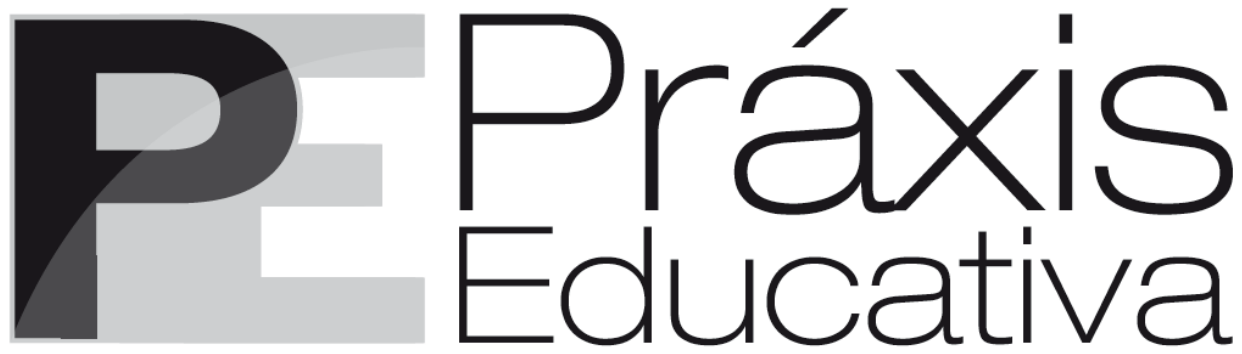

ISSN 1809-4309 (Versão online)

DOI: 10.5212/PraxEduc.v.13i3.0021

\title{
Cartografia para pesquisar currículos: um exercício ativo e experimental sobre um território em constante transformação
}

\section{Cartography to research curriculum: an active and experimental exercise on a territory in constant transformation}

\section{Cartografía para investigar currículos: un ejercicio activo y experimental sobre un territorio en constante transformación}

\author{
Glaucia Conceição Carneiro* \\ Marlucy Alves Paraíso**
}

\begin{abstract}
Resumo: Este artigo explora itinerários de pesquisa em currículo lançando mão de uma cartografia que implementa três linhas de criação, a saber: "Caminhar", "Compor com as sensações" e "Acionar o riso". O argumento explorado é o de que esses três movimentos de "caminhar", "compor" e "rir" acionam dois combates: um combate-contra as máquinas de Estado em suas maquinações e operações, que, no campo do currículo, tem priorizado a forma e a normalização dos corpos; e, também, um combate-entre as forças de pensamento que, ao operar com as "ideias-forças" da Filosofia da Diferença de Gilles Deleuze, busca fazer aparecer pequenas rupturas com "as normas" e "as formas". Tais movimentos compõem o objetivo maior de uma cartografia em curso que visa mapear as intensidades dos encontros acionados pelas performances de uma artista queer na cidade de Belo Horizonte. Esses encontros são disparadores de saberes que constroem um currículo nômade: o "Currículo da cidade com a Arte", que será aqui explorado.
\end{abstract}

Palavras-chave: Cartografia. Composição. Pesquisa em currículo.

Abstract: This paper explores the research itineraries in the curriculum using a cartography that implements three lines of creation, namely: 'Walk', 'Compose with sensations' and 'Trigger the laughter'. The argument explored is that these three movements: 'walk', 'compose' and 'laugh' trigger two combats: a combat-against the State machine, in its machinations and operations, which, in the field of curriculum, has prioritized the form and normalization of bodies; and also a combat-between the forces of thinking that, when operating with the ideas-forces of Gilles Deleuze's Philosophy of Difference seeks to make small openings in the 'norms' and 'forms'. Such movements make up the main objective of an ongoing cartography that aims to map the intensity of the encounters unleashed by the performances of a queer

\footnotetext{
* Doutoranda da Linha de Currículos, Culturas e Diferença do Programa de Pós-Graduação da Faculdade de Educação da Universidade Federal de Minas Gerais (UFMG). Bolsista do CNPq. E-mail: $<$ glaucia.carneiro.bh@gmail.com>.

** Professora associada e coordenadora do Grupo de Estudos e Pesquisas em Currículos e Culturas (GECC) da Faculdade de Educação da UFMG. Pesquisadora do CNPq. E-mail: <mparaiso@fae.ufmg.br>.
}

Práxis Educativa, Ponta Grossa, v. 13, n. 3, p. 1003-1024, set./dez. 2018 Disponível em: <http://www.revistas2.uepg.br/index.php/praxiseducativa > 
artist in the city of Belo Horizonte, Minas Gerais, Brazil. These encounters are triggers of knowledge that build a nomadic curriculum: the Curriculum of the city with Art, which will be exploited here.

Keywords: Cartography. Composition. Curriculum research.

Resumen: Este artículo explora los itinerarios de investigación en currículo utilizando una cartografía que implementa tres líneas de creación: "Caminar", "Componer con las sensaciones" y "Accionar la risa". El argumento explorado es que estos tres movimientos: "caminar", "componer" y "reír" desencadenan dos combates: un combate-contra las máquinas de Estado, en sus maquinaciones y operaciones, que en el campo del currículo, ha priorizado la forma y la normalización de los cuerpos. También es un combate-entre las fuerzas del pensamiento que, al operar con las "ideas-fuerzas" de la Filosofía de la Diferencia de Gilles Deleuze, busca hacer aparecer pequeñas rupturas con "las normas" y "las formas". Tales movimientos componen el objetivo mayor de una cartografía en curso que pretende mapear las intensidades de los encuentros desencadenados por las performances de una artista queer en la ciudad de Belo Horizonte, Minas Gerais, Brasil. Estos encuentros son disparadores de saberes que construyen un currículo nómade: el "Currículo de la ciudad con el Arte", que será aquí explorado.

Palabras-clave: Cartografía. Composición. Investigación en currículo.

\section{Introdução}

A Cartografia é uma prática investigativa de caráter aberto, que se faz em movimento, experimentando e explorando um território. Inspirada nos trabalhos de Gilles Deleuze e Felix Guattari, ela tem sido atualizada em pesquisas de diferentes campos do conhecimento, e sempre fazendo movimentar os objetos pesquisados, os corpos, as coisas e o pensamento. Os movimentos na cartografia não são feitos em linha reta e nem de modo circular. Movimenta-se em ziguezague, para todos os lados, seguindo e explorando as sensações, as pequenas percepções e os efeitos dos encontros. Como encontros improváveis que sempre se dão em um território investigado, inclusive nos currículos que se querem ordenadores, a cartografia não pode ser experimentada com base em um único saber. É sempre necessário fazer composição com saberes variados, diferentes, desiguais, díspares.

Tendo, portanto, o movimento como um importante princípio da cartografia, operacionalizamos, em nossas pesquisas curriculares, procedimentos exploratórios e experimentais que se referem à busca por uma "familiaridade" e uma "intensidade" com o investigado. Ao mesmo tempo que exploramos um território - de um currículo ou qualquer outro território -, procuramos, também, vivenciar os efeitos das múltiplas variáveis que interferem na pesquisa. Tais procedimentos ancoram-se na noção de experiência ${ }^{1}$, entendida aqui como uma produção que é epistemológica e, também, ética, estética e existencial.

Movimentar, explorar e experimentar em uma prática investigativa cartográfica é abrir-se e inundar-se para as conexões e as composições que o próprio investigar possibilita. Essa abertura tem sido bastante importante para as pesquisas em educação, de um modo geral, e para as pesquisas em currículo, de um modo particular, porque obriga esses campos a expandirem seus objetos, saírem das demarcações usuais e fazerem conexões outras com a arte, com a literatura, com o cinema, com a Filosofia. Obriga esses campos a fazerem conexões também, por exemplo, com o sujo, com o desordenado, com o bagunçado e com o imprevisível mundo das ruas, dos

\footnotetext{
${ }^{1}$ A experiência, como aqui a compreendemos, inspirada em Jorge Larrosa (2002), requer que "[...] algo nos aconteça ou nos toque". Isso requer "parar", parar para pensar, para olhar, para escutar. Pensar mais devagar, olhar mais devagar, escutar mais devagar. Parar para sentir, deter-se nos detalhes, “[...] suspender a opinião, suspender o juízo, suspender a vontade, suspender o automatismo da ação, cultivar a atenção e a delicadeza [...]” (LARROSA, 2002, p. 20-28).
}

Práxis Educativa, Ponta Grossa, v. 13, n. 3, p. 1003-1024, set./dez. 2018 Disponível em: <http://www.revistas2.uepg.br/index.php/praxiseducativa> 
pátios das escolas, dos parques, das praças; enfim, da cidade, onde tudo pode acontecer, onde muitas coisas acontecem, mas, muitas vezes, mesmo olhando, não "enxergamos".

Fazer cartografia é fazer micropolítica, porque se trata de exercer uma operação pragmática sobre o mundo. Trata-se de envolver-se com o mundo, ter um comprometimento com sua produção, com base no conhecimento que se tem dele. A Micropolítica é entendida aqui tal qual a define Laymart Garcia dos Santos $(2016)^{2}$ em termos de menor permeabilidade ao Estado, aos seus pressupostos e modos de captura disparados pelo Neoliberalismo em escala planetária. Aderir à Micropolítica não significa abandonar a Macropolítica, nem dar as costas ao combate contra a enorme desigualdade econômica e social que assola o mundo, mas movimentar a um tipo de ação multitudinária que vem acontecendo, principalmente, nas periferias brasileiras que coloca em cena novas personagens e suas coreografias políticas, baseadas em um artivismo ${ }^{3}$ micropolítico.

Para fazer micropolítica, a cartografia "acompanha processos” (KASTRUP et al., 2009, p. 52). O processo, que tem relação com o meio, com o presente, com o virtual, na cartografia, é inerente ao conceito de "criação". Isso porque o processo é resultado do impulso criador, trata-se do "virtual", o que ainda está em vias de "tornar-se" (DELEUZE, 1996). Assim, a cartografia não representa objetos e, por isso, o início e o fim (ou as conclusões) perdem importância para o que acontece no meio, no espaço entre o início e o fim da investigação. Acompanhar processos demanda, portanto, uma ação por inteiro no território cartografado. Significa co-implicar-se! Isto é, tomar a busca pelo conhecimento como um conjunto de acontecimentos, prolongamentos, composições, encontros, agenciamentos e percursos são os elementos de uma cartografia. Tratase de uma prática investigativa sempre aberta $e$ inventiva $e$ que necessita compor com matérias e materiais dispares por tratar-se de movimentações éticas, estéticas e políticas, que consideramos de grande importância para as investigações em currículo que pretendemos abordar neste artigo.

Há, portanto, na cartografia, uma aposta ética-estética-política que se ampara na construção de procedimentos investigativos mais abertos às conexões diversas, que permitam questionar e, até mesmo, ultrapassar muitos pressupostos presentes em abordagens de pesquisas mais convencionais. Como em nossa perspectiva a cartografia é entendida como uma "pragmática" ou um exercício ativo do/a investigador/a sobre o mundo, ela se faz caminhando. Por isso, constitui-se por modos de investigar estranhos para quem demanda procedimentos de pesquisas decididos a priori, mas que tem se mostrando muito importante no campo educacional para quem deseja investigar-experimentando, deslocando permanentemente o pensamento e o corpo e, assim, produzir intervenções sob o pesquisado e sobre o mundo.

Por isso, exploramos, neste artigo, três linhas de criação de uma cartografia que se faz sempre em movimento e movimentando as coisas: "Caminhar", "Compor com as sensações" e "Acionar o riso", que expressam o rastro das movimentações que cartografamos nos territórios curriculares pesquisados e em nós mesmas. $\mathrm{O}$ argumento aqui desenvolvido é o de que, ao "cartografarmos caminhando", "compormos com as sensações" e "acionarmos o riso", movimentamos as forças necessárias para realizar dois combates importantes na educação e no currículo: o combate-contra as formas que querem nos aprisionar; e o combate-entre as forças que movimentam e aumentam a nossa potência de agir ao se combinar com outras forças, possibilitando a criação do "novo". Esses movimentos foram movimentados por uma cartografia

\footnotetext{
${ }^{2}$ Laymert Garcia dos Santos explorou esta "noção de micropolítica" em uma conferência proposta pelo "Programa de Ações Culturais Autônomas", realizada na "Casa do Povo" (São Paulo, 12/11/2015). O vídeo da apresentação encontra-se disponível em: <https://vimeo.com/153449199>.

3 Ações "multitudinárias" e "artivismo" referem-se às "[...] novas modalidades de insubmissão, de rede, de contágio e de inteligência coletiva", discutidas, sobretudo, por Negri e Hardt (2005, p. 84).
}

Práxis Educativa, Ponta Grossa, v. 13, n. 3, p. 1003-1024, set./dez. 2018 Disponível em: <http://www.revistas2.uepg.br/index.php/praxiseducativa> 
em curso que busca mapear os encontros intensivos, disparados pelas performances de uma artista queer na cidade de Belo Horizonte.

Desse modo, entendemos que cartografar aciona um duplo movimento. Trata-se de um duplo movimento porque, para Deleuze (2017), a teoria não "expressa”, não "traduz", não "aplica" uma prática. A teoria já "é uma prática". Tal prática faz-se movimentando as forças e combatendo as formas, mas, também, criando e experimentando composições que fazem da pesquisa um "ato de criação". Ao praticar esse exercício de movimentar as forças e desmanchar as formas, este artigo experimenta mostrar como o caminhar, o compor e o rir podem ser procedimentos singulares da cartografia em educação, no geral, e do currículo, em particular, para experimentar suas invenções, fabulações, conexões e acoplamentos que fazem "um currículo coincidir com a vida" (PARAÍSO, 2015, p. 270). O objetivo deste artigo é, portanto, discutir estes três movimentos: "caminhar", "compor" e "rir" como procedimentos cartográficos que acionam um "combate-contra" as máquinas de Estado. É, também, um "combate-entre" as forças de pensamento que, ao operar com os conceitos da Filosofia da Diferença de Gilles Deleuze, busca fazer aparecer pequenas rupturas com "as normas" e "as formas", demonstrando como o agenciamento entre 'cidade' e 'arte' aciona um currículo nômade: o "Currículo da cidade com a Arte".

\section{Cartografar-Caminhar}

É possível experimentar o caminhar como uma ferramenta de trabalho relevante em uma cartografia no campo do currículo. Elegemos como uma linha de força importante a questão do movimento dos corpos e dos deslocamentos, tanto físicos como no pensamento, que esse movimentar nos provoca. Sob tal ponto de vista, tomamos o caminhar como mote e ferramenta para discutirmos alguns de seus usos e de seus efeitos durante nossos percursos cartográficos. Esse caminhar, como temos operacionalizado, tem se desdobrado em múltiplas formas. Ultrapassando os limites de um mero procedimento físico, como o de se deslocar "do ponto A ao ponto B" no território pesquisado, é assumido aqui como um componente epistemológico e existencial relevante. O caminhar adquire, assim, os contornos de um "caminhar-pensar" [com Nietzsche], "caminhar-outrar" [com Foucault] e "caminhar para movimentar os devires" [com Deleuze]. Contudo, é preciso estarmos atentas, porque, para Deleuze (1992), a velocidade ou o ritmo dos nossos passos influencia uma trajetória. Ele sugere: "Não agitar demais para não espantar os devires" (DELEUZE, 1992, p. 172). De fato, caminhar em ritmos alternados altera a forma como enxergamos o mundo e as coisas do mundo.

É certo que aprendemos com o corpo todo e o ritmo do corpo permite aprendizagens distintas. Para Tim Ingold (2015), por exemplo, "viver" implicaria "mover-nos" para que possamos apreender o mundo e a nós mesmos. Assim, "mover", "conhecer" e "aprender" demandam, segundo Ingold (2015), mais do que um "estar em" ou uma espécie de "imersão" no espaço; demandam uma espécie de atenção que significa "estar vivo para o mundo". Ingold (2015) argumenta que a tradição ocidental privilegiou a visão em detrimento do tato, do contato. Houve uma ascensão da cabeça sobre os calcanhares. Essa ruptura com os pés tornou-se problemática, uma vez que é com os pés que "mantemos um contato maior com o entorno" (INGOLD, 2015, p. 70). A experiência corporificada do movimento de pedestres foi cedendo lugar a uma espécie de "cultura sentada". Segundo Ingold (2015), a cadeira "priv[ou] os usuários da possibilidade de pensarem com os pés” (INGOLD, 2015, p. 86).

\footnotetext{
${ }^{4}$ Devir é um dos principais conceitos criados por Deleuze e Guattari para explorar as forças que, em movimento em um corpo, o agita e o transforma (DELEUZE; GUATTARI, 1995a, 1995b, 1997).
}

Práxis Educativa, Ponta Grossa, v. 13, n. 3, p. 1003-1024, set./dez. 2018 Disponível em: <http://www.revistas2.uepg.br/index.php/praxiseducativa> 
As ideias desenvolvidas sobre os "Modos de Estar no Mundo" de Ingold (2015), agenciadas ao "Pensamento do Fora" desenvolvidos por Blanchot (1997), Deleuze (2005) e Foucault (2013), levaram-nos a assumir as perguntas: "Como aprendemos com o corpo?" e "Como aprendemos caminhando?", que andaram junto às cartógrafas durante toda a investigação que dá base a este artigo. As cartógrafas também foram se modificando no processo, se deslocando e se desdobrando, na medida em que, ao longo da cartografia, assumíamos "o caminhar" e sua "relação com o Fora", com outros "modos de pesquisar" e de "produzir saberes" em um currículo. Com Blanchot, entendemos que o pensamento do "Fora" é uma experiência que se dá "sob o signo do acaso, da força e/ou do desconhecido" (PELBART, 1993, p. 95), no momento que a "abertura" a esse "Fora" "torna-se a mais absoluta das entregas" (PELBART, 1993, p. 97). Buscamos, então, em nossa cartografia, uma atitude de mais intensificação com o Fora, com a exterioridade. O Fora é entendido, neste artigo, como a experiência de uma exterioridade que "desapossa" o sujeito de um "si" e do mundo, transformando-o.

Deixamo-nos seduzir pela "sensação de liberdade" e pela "fruição da alegria" ao cruzarmos os portões da escola e procurarmos saídas, aberturas para um currículo já quase asfixiado por tanta imobilidade. Ousamos sair (da escola e de nós mesmas) e promover fissuras no currículo para que ele possa respirar melhor: "um pouco de possível senão eu sufoco" (DELEUZE, 1992, p. 131); para que o currículo pudesse arejar-se, sentir o vento, deliciar-se com o calor do sol, e, assim, tornar-se um currículo vibrante, errante, cambiante e nômade (PARAÍSO, 2015). Um currículo que dança e faz piruetas; um currículo-moleque-de-rua que não tem medo de vaguear e se sujar com a cidade ao catar as latinhas e os signos que encontra pelo caminho. Para tudo isso, na cartografia do "Currículo da cidade com a Arte", foi necessário caminhar e compor com a política; caminhar e compor com a arte e caminhar e compor com a ética. É isso que exploramos a seguir.

\section{Caminhar e criar com os pés}

"Peregrino/a", "pedestre", "caminhante", "andarilho/a", "errante", "nômade", e, ainda, "flanêur", "walker", "wanderer", "stalker" são formas de referir-se às pessoas que se deslocam por trilhas ou espaços urbanos com os próprios pés. Além da dimensão da questão da "mobilidade pedestre" ser, hoje em dia, uma maneira de resistência ecopolítica ao modelo de "mobilidade automotor", caminhar sempre foi um ato político, presente em manifestações, protestos, passeatas e marchas. Quem no Brasil não se lembra da célebre música que o cantor e compositor Geraldo Vandré apresentou em 1968, no III Festival Internacional da Canção, intitulada: Pra não dizer que não falei de flores? A música convocava: "caminhando e cantando e seguindo a canção/ Somos todos iguais braços dados ou não/ Nas escolas, nas ruas, campos construções/ Caminhando e cantando e seguindo a canção".

Tal música tornou-se um apelo para a necessidade de uma "unidade" para se atingir a mudança do contexto político em que o povo brasileiro vivia e que era um regime militar de grande opressão, sofrimento, instabilidade econômica, social e política. A música, que passou a ser chamada de "Caminhando", expressava força, inconformidade e chamava para a luta, para a mudança. Tornou-se "um hino" de resistência do movimento estudantil, que fazia oposição à ditadura militar brasileira. Ela foi censurada porque seu refrão - "Vem, vamos embora / Que esperar não é saber / Quem sabe faz a hora, / Não espera acontecer" - foi considerado uma chamada à luta armada contra os ditadores. Na canção, Geraldo Vandré convoca-nos "a caminhar", "sair do lugar", "se implicar", "lutar".

Práxis Educativa, Ponta Grossa, v. 13, n. 3, p. 1003-1024, set./dez. 2018 Disponível em: <http://www.revistas2.uepg.br/index.php/praxiseducativa> 
O caminhar na prática investigativa de uma cartografia também demanda das cartógrafas que estas "saiam do lugar", "se movimentem", "se impliquem", "busquem as entradas e as saídas" em um currículo, como sugerem Paraíso (2010) e Paraíso e Caldeira (2018). Caminhar é, de fato, um ato político porque demanda deslocamentos físicos e deslocamentos no pensar. Isso faz toda a diferença na prática investigativa em educação: nada de acusarmos "o outro" de fixidez! Nada de demandar que "o outro" mude! Nada de, com nossas investigações, repetir que "o outro" não sai do lugar. Somos nós que, na cartografia, caminhamos $e$ saímos do lugar $e$ nos implicamos $e$ revemos $e$ lutamos $e$ fazemos micropolítica. Para isso, o investimento de nossos "pés" na rua não se efetua na "forma" da re-invenção de uma nova "utopia"; mas, sim, na "força" de uma "heterotopia", no "laboratório" de experimentações corporais que deseja, não a transformação deste mundo, mas a criação de outro(s) mundo(s) no aqui e agora.

\section{Caminhar e criar com arte}

Como um ato estético, caminhar tem sido crucial em muitos movimentos de vanguarda artística do "Dadaísmo", do "Surrealismo" ao "Situacionismo" e além. Mais recentemente, tem se manifestado nas "Land Art" e nas "Performances". Tais experiências exploradas por Paola B. Jacques (2003) e Francesco Careri (2013), em suas pesquisas, apontam para a descoberta das errâncias como uma espécie de inscrições que deixam marcas na cidade. O deslocamento estético consiste, portanto, em sair de uma cidade mais visível e rotineira, mais praticada e conhecida de todos/as, para fazer ver o que a arte faz de melhor que é "extrair os devires" das coisas (DELEUZE; GUATTARI, 2007). O caminhar desdobra-se, portanto, na oportunidade de se realizar um duplo deslocamento para artistas que experimentam o deslocamento físico em seu processo criativo. É duplo porque prevê um movimento físico (nas formas) e o outro, intensivo (nas forças, nas sensações).

Dentre os/as artistas errantes, andarilhos/as e nômades que fazem trilhas no interior e na cidade encontram-se escritores/as, poetas e/ou pensadores/as que praticaram o caminhar como obra ou como fonte de inspiração. Por meio das obras ou escritos de artistas, é "possível apreender o espaço de outra forma" (JACQUES, 2008, p. 5). A arte de caminhar pode, então, ser uma linha de força que dá consistência ao percurso da "liberdade", como em Hölderlin que, em um de seus poemas, convida um amigo para saírem juntos a fim de absorverem e explorarem "o aberto"; ou em Baudelaire, seus escritos sobre "o flanêur" e as "perambulações" despretensiosas dessa personagem pelas ruas de uma Paris em processo de metamorfose ${ }^{7}$. Benjamin (1994) também praticou a "flânerie" e debruçou-se crítica e poeticamente sobre tal temática (BENJAMIN, 1994). Já a escritora Virgínia Woolf evocou um bloco de sensações e devires ao escrever os sentimentos de uma personagem que caminhava entre o vai-e-vem dos/as pedestres locais e o burburinho das ruas de um centro comercial de Londres (WOOLF, 2014).

\footnotetext{
${ }^{5}$ Heterotopia foi um conceito elaborado por Foucault (2013) para se referir a "outros espaços", diz respeito, na verdade, aos usos insurgentes que podemos fazer dos espaços, subvertendo a linguagem e suas práticas de nomeação, identificação e ordenamento do mundo, em um exercício de "deslocamento" e de "desvio".

${ }^{6}$ No poema "Paseo en el campo", o poeta afirma: "Ven hacia lo abierto, amigo/ aunque hoy día poca luz esplenda todavía y que el cielo no sea una prisión/ni la cima de los bosques, ni siquiera las montañas pudieron expandirse como hubiéramos querido/ Y el aire se queda sin voz. Está sombrío, las calles y los caminos duermen /Y por poco, me creería haber vuelto a la edad de plomo/Sin embargo una voz ejerce la fe justa/ y esa voz aún no ha sido apagada por un momento. Disponível em: <https://pensamientosyotrosescritos.wordpress.com/tag/holderlin/>. Acesso em: 15 jul. 2018.

7 O flâneur é um observador da vida urbana. Especificamente tratando do contexto histórico no qual escreveu Baudelaire, na sociedade francesa - e mundial - em meados do século XIX, o levaram a questionar se as ideias estéticas tradicionais eram - ou não - adequadas ao dinamismo da nova sociedade. Caminhar, observar e imaginar: talvez sejam as três palavras que melhor definem a atividade do flanêur.
}

Práxis Educativa, Ponta Grossa, v. 13, n. 3, p. 1003-1024, set./dez. 2018 Disponível em: <http://www.revistas2.uepg.br/index.php/praxiseducativa> 
A caminhada como experimentação estética esteve presente tanto na constituição das vanguardas como nas marchas, nos manifestos surrealistas de André Breton e nas derivas experimentadas por Guy Debord e suas experimentações situacionistas. Mais recentemente, caminhar aparece como o disparador dos "site-specifics" na "Land Art" dos celebrados trabalhos de Richard Long, Robert Smithson, Janet Cardiff e Francis Alÿs. Em relação às caminhadas como objeto de obra de arte, não podemos nos esquecer das Performances, entre elas, destacamos a implementada por Flavio de Carvalho, artista carioca que causou furor nos/as habitantes da cidade do Rio de Janeiro ao implementar uma caminhada pelas calçadas da cidade usando "saias" ao invés de "calças", em $1956^{8}$.

O caráter transgressivo da arte é o que dá acesso às questões fundamentais da existência, sem, todavia, ser preciso instaurar uma "metafísica", uma "transcendência" com o viver. O caráter experimental e modular da arte é o que agita e faz vibrar "as intensidades", que são entendidas por Deleuze (2007) como regiões da matéria onde se formam "ondas de variações" e "potências" que atravessam o real e desequilibram as normas. O caminhar como obra de arte pode ser tomado assim como "[...] esse estado celestial que nada guarda de pessoal e racional. A sua maneira a arte diz o que dizem as crianças. Ela é feita de trajetos e devires, por isso faz mapas extensivos e intensivos" (DELEUZE, 1997, p. 78).

Em uma cartografia, o caminhar adquire a dimensão estética de uma criação, de uma experimentação. Trata-se de, com a pesquisa curricular (ou em outro território), fazer experimentações ambulantes, itinerantes e desterritorializantes que se ligam à concepção de "ciência menor" (DELEUZE; GUATTARI, 1997), que exige de nós cartógrafas exatamente "seguir, caminhar". Experimentações nômades que se ligam a uma "máquina de guerra", em que os fluxos do território a ser explorado se repartem. Experimentações problemáticas que subordinam nossas investigações às condições sensíveis da "intuição" e da "criação", tanto na pesquisa quanto das próprias pesquisadoras-cartógrafas.

\section{Caminhar e criar com a ética}

Deleuze encontra na ética de Espinosa uma alternativa para a doutrina da moral e do "juízo", fundada em valores transcendentais, considerados superiores à vida, que tomam como referência "as normas". Para Deleuze (2017), é importante pensar o aspecto ético em seu potencial "cinético" ou "dinâmico" em que as partes extensivas de um corpo se "afectam", sendo tal relação sempre inseparável das forças de ser "afectado", quer dizer, da relação que o ser estabelece com tais forças. A ética em Deleuze diz respeito, sobretudo, às potências e aos poderes em ação em uma vida. A afecção é, portanto, o estado de um corpo quando ele sofre a ação de outro corpo. Trata-se sempre de uma mistura de corpos.

Nesse sentido, caminhar em uma cartografia dá-se na ordem dos encontros e das composições. Os "afectos" são os graus das afecções pelas quais a potência de agir de um corpo é diminuída ou aumentada. A teoria dos "afectos" de Espinosa tem grande importância para Deleuze e, também, para nosso caminhar-compor como um procedimento das cartografias que fazemos de currículos. Os encontros em uma cartografia disparam "afectos" que envolvem, ainda, uma relação direta do presente com o passado e o futuro em uma "duração" contínua, em um estado de "transição", "passagem" ou "variação" de um grau da afecção a outro.

\footnotetext{
${ }_{8}$ Disponível em: <http://dasartes.com.br/agenda/flavio-de-carvalho-caixa-cultural-brasilia/>. Acesso em: 15 jul. 2018.
} 
O caminhar como uma prática ética dos "afectos" nos apresenta a cidade pela lógica do "palimpsesto", que aciona "outras" cidades dentro da cidade concreta de "pedra" e "carne". "Cidade(s)" que não aparece(m) nos guias turísticos, nos anúncios publicitários e nem nos livros didáticos dos currículos escolares. Trata-se do encontro com a cidade "labiríntica", como a experimentada pelo artista Hélio Oiticica e suas perambulações pelos morros cariocas nos anos sessenta. Ou a cidade "nômade" dos "Stalkers" do arquiteto italiano Francesco Careri e seus estudantes, com suas longas caminhadas por uma Roma pouco conhecida. Ou, ainda, a cidade "heterotópica" de um grupo de arquitetos portugueses que se autodenomina de "os Espacialistas ${ }^{10}$ " que, em suas andanças, e ocupando com seus corpos os mais diferentes espaços, muda completamente os territórios. Em todas essas experiências subversivas, nômades e transformadoras, o caminhar constitui-se um modo ético de se colocar no mundo ao realizar uma crítica dos processos que sobrecodificam o espaço urbano.

Caminhar é, portanto, uma "forma de desobediência" (GRÓS, 2010), quer dizer, uma maneira estética de fundar outras éticas. Caminhar em uma cartografia curricular (ou de outro território) envolve uma espécie de "liberdade" suspensiva, isto é, a criação de um vetor de mudança, "uma linha de fuga" provocada por uma desconexão em relação aos modos de vida "espetacularizados" de captura de nossos corpos hoje em dia. Caminhar é uma pragmática existencial imbricada em "exercícios" ou "práticas de si" (FOUCAULT, 2004) ativadas por "operações de si sobre si mesmo", capazes de transformar e constituir para "si" uma "forma mais estilística de vida" (FOUCAULT, 2004, p. 199).

Em uma abordagem mais antropológica, poderíamos afirmar que caminhar sempre foi uma prática vital para a sobrevivência de nossa espécie, sendo vital também para as investigações em Educação que desejem co-implicar-se na construção de outros mundos, considerando as múltiplas realidades que construímos nesta vida em resposta às diferentes necessidades que criamos. A "imanência" constitui, assim, aquilo que nos situa no ordinário da realidade e não fora ou superior a ela. Por tudo isso, na cartografia que fazemos, "o caminhar" não é apenas uma forma de deslocamento, mas uma disposição afirmativa, que encontramos em Nietzsche (1995), que foi um caminhante tenaz, de ficar sentadas o menor tempo possível e desconfiar dos pensamentos que não tenham nascido ao ar livre (NIETZSCHE, 1995, p. 70). Desse modo, por onde caminhamos, abrimos trilhas e inventamos uma cartografia que experimenta e explora o mundo, movimentando o pensamento.

\section{Caminhar e criar territórios investigativos móveis}

No livro Em defesa da escola, uma questão pública, Jan Masschellein e Marteen Simons (2014) afirmam que a antiga palavra grega "scholé", que deu origem à palavra "escola", sofreu uma transmutação na transição da Idade Média para a Modernidade, e, se antes fulgurava como "tempo livre", a lógica da produtividade do Capitalismo transformou-a em "local de concentração e de estudo", um espaço repleto de cadeiras, mesas e sem "pés em movimento". Fixar, e não caminhar, eis o chamado da escola. O modo de vida sedentário codificou as práticas escolarizadas, encontrando no espaço escolar uma forma de "docilizar" os corpos e dificultar o deslocar-se. Além disso, se os sapatos privaram os/as usuários/as da possibilidade de pensarem com os pés, as cadeiras permitiram-nos pensar sem absolutamente envolver o resto do nosso corpo. De acordo com Ingold (2015), o sapato e a cadeira foram os responsáveis por separar “o

\footnotetext{
9 Disponível em: <http://www.spatialagency.net/database/why/political/stalkerosservatorio.nomade>. Acesso em: 15 jul. 2018.

${ }^{10}$ Disponível em: <http://www.e-cultura.sapo.pt/artigo/6674> . Acesso em: 15 jul. 2018.
}

Práxis Educativa, Ponta Grossa, v. 13, n. 3, p. 1003-1024, set./dez. 2018 Disponível em: < http://www.revistas2.uepg.br/index.php/praxiseducativa> 
pensamento da ação", “a mente e o resto do corpo" (INGOLD, 2015, p. 87). O aprendizado escolar centrou-se na cabeça e divorciou-se do resto do corpo.

O caminhar que possibilita deslocarmo-nos, saímos do lugar, movermo-nos, mobilizarmo-nos, acabou ficando bem longe das práticas escolarizadas. Em vez de caminhar, em nossas escolas, a prática comum é o fixar. Muitas pesquisas em educação acabaram fazendo o mesmo: ficamos quietinhas descrevendo (tentando ser o mais fiel possível) e analisando nossos "dados". No entanto, a cartografia sabe que essa fidelidade é impossível. A cartografia (re)quer mesmo é o movimento, é caminhar experimentando e mostrando que qualquer intervenção em um território muda tudo.

Do mesmo modo que caminhar é tão difícil para a escola, assim o é para muitos pesquisadores e muitas pesquisadoras em educação, que preferem ficar quietos/as imersos/as em seus "dados" ou nas suas informações. De fato, caminhar pode ser uma verdadeira aventura em uma investigação. Andar por uma via urbana, sobretudo nas grandes metrópoles latinoamericanas, tem sido uma prática cada vez mais difícil e penosa para os/as pedestres, devido ao barulho, à sujeira, à precariedade dos transportes urbanos e aos riscos da violência. Por isso, a grande maioria dos/das habitantes da cidade, que tem condições de comprar um carro, prefere se deslocar para o trabalho de automóvel e, às vezes, frequentar shoppings centers a ter de caminhar em parques ou nas áreas públicas da cidade, como uma alternativa de lazer.

Caminhar possibilita encontros imprevistos e imprevisíveis nas grandes cidades. A mesma dificuldade de caminhar também dificulta o abrir-se às experimentações e às experiências que compõem uma variedade de possibilidades em uma pesquisa. As cidades estão cada vez mais acinzentadas, poluídas e tomadas por mais e mais carros. As grandes metrópoles são pensadas e planejadas para os veículos e não para as pessoas. Com o uso excessivo dos carros nas ruas, o caminhar vai deixando de ser uma necessidade e passando a ser uma contingência ou, ainda, uma escolha ética, estética e política nem sempre fácil de sustentar. Entretanto, há quem persista em experimentar a cidade, em enfrentá-la, senti-la ou vivê-la. É muito importante pensar a cidade, pensando também na pessoa "que nela habita", naquele/a que nela "vive ou sobrevive" (BONAFÉ, 2010, p. 442), pois a cidade ensina muito às pessoas que nela vivem. Ela pode ensinar sobre as intensidades dos encontros que nela acontecem todos os dias.

A noção de cidade que assumimos em nossa cartografia é a de que a cidade é um currículo, um território que ensina ao disparar signos e "afectos", que podem ser trans-in-corporados por quem caminha pelas ruas. Por tudo isso, caminhar e deslocar-se a pé na cidade é aprender a compor um repertório, cuja dimensão pragmática, apesar de difícil para alguns/mas, tornou-se um componente importante na cartografia do "Currículo da cidade com a Arte". Ao agenciar a noção de currículo da cidade com o caminhar de um modo ético, estético e micropolítico, percebemos que inventávamos a ferramenta do caminhar-compor em nossa metodologia, à medida que explorávamos uma ampliação da noção de currículo, já que o currículo foi tomado na cartografia como uma "máquina política e experimental que transforma experiências", que "[...] leva professora(s) e alunos/as a caminhos novos[...] ", que "[...] produz metamorfoses, sentidos e emite signos" (PARAÍSO; CALDEIRA, 2018, p. 46).

Assim o currículo, que tem sido "[...] tradicionalmente vivido entre as paredes de uma sala de aula" (BONAFÉ, 2010, p. 443), pode expressar-se como um diagrama aberto, que possibilita encontros, contágios e significações variadas. O currículo da cidade é um currículo singular por ensinar sem pré-requisitos, sem metas e sem avaliações de desempenho. Trata-se de um currículo que lida com o imprevisível e o improvável e que, por isso, possibilita composições e aprendizagens inusitadas (PARAÍSO, 2015). Tal currículo é desdobrado como um campo de investigação ainda pouco explorado.

Práxis Educativa, Ponta Grossa, v. 13, n. 3, p. 1003-1024, set./dez. 2018 Disponível em: <http://www.revistas2.uepg.br/index.php/praxiseducativa $>$ 
Por tudo isso, o currículo da cidade com a arte é compreendido aqui como um "diagrama rizomático". Realizamos "mapas" ao modo das "máquinas desejantes", enquanto problematizamos a arte queer" no território urbano como uma criadora de saberes menores, sensações, intensidades e afecções nas pessoas que caminham pelas ruas. Como a arte é responsável por algumas fissuras no espaço urbano, quem caminha nas ruas está mais exposto e tem mais chance de compor com a estética micropolítica, produzida pela arte urbana. Por isso, em nossa cartografia, escolhemos cartografar as derivas de uma artista de rua chamada "Ed Marte" 12 , a fim de compreender as potências que o caminhar ao modo queer provoca nas pessoas que andam pela cidade.

Deleuze (1985) abordou a questão do agenciamento entre "o movimento" e "o espaço", argumentando que não se pode tentar reconstituir o movimento levando em consideração sua "representação". Não se pode partir de "posições fixas no espaço" ou de "instantes no tempo", medidos por "cortes imóveis" (DELEUZE, 1985, p. 6). Por isso, em uma cartografia (curricular) que se afirma itinerante, móvel e nômade, não faz sentido congelar o movimento em representações de uma realidade que por si já é cambiante.

O que uma cartografia pode e sabe fazer é a criação de movimentos novos que, por sua vez, se desdobram em outros e mais outros e assim infinitamente. Uma cartografia pode desenhar movimentos moleques, moleculares e intensivos, disparados pelos encontros disparados pelas artistagens de um currículo nômade. Por isso, uma cartografia deve ser lida pela lente de uma teorização híbrida, sendo transcrita, trans-escrita, de maneira performática nos gestos e nos traços de uma narratividade singular. Para criar "o novo" em uma pesquisa da área da Educação, não é suficiente, apenas, cartografar-caminhar; é importante, também, desenvolver um cartografarcompor, que exploramos a seguir.

\section{Cartografar-compondo com as sensações}

Cartografar é fazer composições que surgem do combate que travamos contra a forma, quer dizer, contra o congelamento do sujeito e do objeto em uma dada pesquisa. Em uma composição, não importa "a forma", "a substância", mas "o que se passa entre", entre o sujeito e o objeto, entre a cartógrafa e seu território. Fazer uma composição em uma pesquisa cartográfica implica colocar as perguntas de um modo diferente. Não perguntar: "o que é isso?", mas inquietar-se: "o que isso pode fazer?" e "o que posso fazer com isso?".

As cartógrafas tornam-se uma espécie de "artistas" enquanto compõem sua cartografia. As cartógrafas "criam" e "criam-se" ao fazer as composições sensoriais, sonoras, "afectivas", diagramáticas e escritas. Fazem mapas-composições, diagramas-móveis-portáteis como o que nos deparamos na canção "Deixe-me ir", de Antônio Candeia, imortalizada na voz de Cartola: Deixeme ir, preciso andar/Vou por aí a procurar/Rir pra não chorar/Quero assistir ao sol nascer/Ver

\footnotetext{
${ }^{11} \mathrm{O}$ uso do termo queer pela cultura popular vem se tornando cada vez mais comum nas últimas décadas. A origem remonta a fins dos anos 1980, nos EUA, como resposta ao padrão de gênero binário, às normas, à opressão social e a tudo que diverge que é excêntrico esquisito e diferente (SPARGO, 2017). Apesar de compreender as críticas que são feitas às apropriações de termos, expressões e teorias estrangeiras, sobretudo pelo pensamento pós-colonial (PEREIRA, 2017), para fins deste artigo, optamos por utilizar a palavra "queer", porque o artista, cujas performances cartografamos, se autodenomina uma pessoa queer. Como se declara "sem gênero" ou "gênero neutro", neste artigo, sempre que nos referirmos a Ed Marte, doravante usaremos o artigo no feminino, a fim de ressaltar o movimento de resistência transfeminista assumido por Ed Marte em suas performances.

${ }^{12}$ Nossa pesquisa consiste em cartografar os signos, os saberes e os "afectos" acionados nos encontros que ocorrem entre o público que assiste as performances de rua e uma artista queer chamada "Ed Marte" na cidade de Belo Horizonte.
}

Práxis Educativa, Ponta Grossa, v. 13, n. 3, p. 1003-1024, set./dez. 2018 Disponível em: <http://www.revistas2.uepg.br/index.php/praxiseducativa> 
as águas dos rios correr/Ouvir os pássaros cantar/Eu quero nascer, quero viver. Deixe-me ir, preciso andar/Vou por aí a procurar/Rir para não chorar/Se alguém por mim perguntar/Diga que eu só vou voltar/Quando eu me encontrar.

Em uma cartografia, ao contrário, é importante perder-se. "Perder-se numa cidade, como alguém se perde em uma floresta, requer instrução" (BENJAMIN, 1992, p. 73). Cartografar é deixar-se perder no deserto do território cartografado. É traçar uma rota nômade em um "espaço liso" (DELEUZE; GUATTARI, 1997) e selvagem. Duas linhas atravessam nossa cartografia: a linha do movimento e a linha dos afectos. Da mistura dessas duas linhas compomos o diagrama do Currículo da cidade com a Arte. Não se trata apenas de uma simples "soma", mas da necessidade composicional de "combinar heterogêneos", de disparar encontros entre corpos divergentes entre si, desses corpos com a arte e com a cidade. Trata-se de um currículo traçado a pé, cartografando o território com o corpo todo, na medida em que acompanhamos as performances de uma artista queer na cidade.

Uma composição é sempre estética: “o que não é composto não é uma obra de arte" (DELEUZE, 2007, p. 247). É da arte de se inscrever "no entre" o "conhecimento" e "a sensação". Para atingir a sensação, é importante desmanchar as formas e captar suas forças. A composição que nos interessa em nossa cartografia se dá quando dois conjuntos de potências, duas forças heterogêneas, se combinam, formando um sistema modulatório. Há, nesse movimento combinatório, a composição de graus de intensidade variados. Quando pensamos no encontro entre os corpos em uma cartografia, falamos da composição de corpos e entre os corpos. Pensamos na interatividade produzida no território urbano como produção de forças, que entram em relações variadas de "velocidade" e de "repouso" nos corpos em trânsito pelas ruas da cidade.

No entanto, como cartografar essa dramatização dos corpos com a arte na rua? Com Deleuze e Guattari (1997), compreendemos que um corpo se define por sua "latitude" e "longitude". Assim, pela longitude, um corpo se define "[...] pelo conjunto de elementos materiais que lhe pertencem [...] sob relações de movimento e repouso, de velocidade e lentidão"; e, por latitude, o corpo se define "[...] pelo conjunto dos afectos intensivos de que ele é capaz sob tal poder ou grau de potência" (DELEUZE; GUATTARI, 1997, p. 47). Assim, cartografar um corpo em uma pesquisa implica enumerar seus "afectos".

\section{Compor com os corpos e entre os corpos}

Se alguém nos perguntasse que aspecto consideramos o mais difícil em nossa cartografia, não hesitaríamos em responder, como Foucault (2004) já expressou, que o difícil é sair do que se é, para criar outros possíveis. Tal afirmação inaugura um paradoxo na medida em que o processo de "outramento" é infinito, não-localizável e intemporal. Começa antes da cartografia começar e, mesmo depois de seu fim, ainda se prolonga. Entretanto, é a atualização acionada pela cartografia que escova os clichês, abre as brechas, desfaz linhas e desdobra camadas de experiências anteriores para que o novo possa se efetuar no momento que a cartografia avança. O cérebro, em todos os instantes, diz "eu", mas o "eu" é "outro". Não é "o mesmo"! Não é o mesmo das representações e dos processos cognitivos. Esse "outro" não é somente o outro do "eu conheço", mas também "o outro" do "eu sinto" que surge dos encontros com a arte.

O labiríntico processo de "outrar-se" ocorre durante toda a cartografia do currículo com a arte, ativando novas significações para as noções de "espaço-tempo", "corpo" e "movimento" que, no caso da nossa cartografia, encontram-se agenciadas à composição: currículo + cidade + arte. Nesse sentido, o corpo torna-se uma linha de investigação importante, porque é no/do encontro entre o corpo da artista queer e nômade - autora das performances cartografadas - com o

Práxis Educativa, Ponta Grossa, v. 13, n. 3, p. 1003-1024, set./dez. 2018 Disponível em: <http://www.revistas2.uepg.br/index.php/praxiseducativa $>$ 
corpo dos/as habitantes da cidade e o próprio corpo das cartógrafas, que um circuito de "afectos" é disparado, produzindo o "diagrama" das intensidades e das sensações experimentadas durante a cartografia que realizamos.

O combate-entre as forças é gerado, na cartografia, nesse encontro dos corpos e entre os corpos. Nesse encontro é possibilitada uma espécie de encenação, dramatização, em vez de uma "historização" dos acontecimentos de uma pesquisa. Essa "encenação cartográfica" demanda um tipo de narratividade acionada por outros "valores" (não representativos) e não-linguageiros no sentido de se criar uma "língua menor", mas também na direção do que Deleuze denominou de "substituição" da "história da filosofia" por um "teatro da filosofia" (DELEUZE, 2006, p. 115).

Trata-se de um teatro cartográfico no qual "os papéis" podem mais que "os atores"; "os espaços" mais que os papéis; e "o pensamento" mais que os espaços. Um teatro das "multiplicidades" (DELEUZE, 2006, p. 116) que se opõe, para todos os efeitos, ao "teatro da representação". Não encontramos um sentido de algo sem compreendermos as forças que se apropriam das coisas, que as exploram, se apoderam delas ou se expressam nelas, a fim de criar uma teatralização dos problemas e das perguntas. Perguntas que disparam a cartografia e promovem uma "encenação" de conceitos, encarnados em suas relações diferenciais.

\section{Compor com as sensações de um corpo em trânsito}

Essa espécie de encenação dos corpos em uma cartografia levou-nos a pensar a respeito da questão da modulação das forças e das sensações que interferem e modificam "as corpografias" dos pesquisadores e das pesquisadoras em seus territórios de pesquisa. De que maneiras as forças (as afecções) em ação no corpo da cartógrafa codificam e interferem nos "blocos de sensações" e "perceptos" gerados em uma pesquisa? Para levantar algumas pistas sobre as sensações que atravessam o corpo de quem realiza as cartografias, é que apresentamos trechos do Manual das (Ina)propriações de uma cartografia nômade e queer- uma espécie de diário de campo de cartógrafas e que, ainda, se encontra em fase de construção -, com o objetivo de mostrar como os corpos das pesquisadoras na cartografia tornam-se superfícies de inscrições, atravessadas por diferentes graus vibracionais.

Trata-se, quase sempre, de uma "variação imperceptível" nas "variações potenciais" (os "afectos") que, nos corpos das pesquisadoras, atualiza o "virtual", uma espécie de "corpo virtual" (MASSUMI, 2016) que surge dos encontros entre os corpos das pesquisadoras com os "signos da arte" e, de maneira reversa, com os "signos do mundo". Durante a experimentação cartográfica que acontecia pelas ruas da cidade, havia a "atualização" de um componente virtual acionado pela arte. No entanto, o corpo virtual era frequentemente bloqueado nos encontros com os signos mundanos:

O despertador toca às sete horas. O corpo com sono levanta-se da cama. A água do chuveiro desce da cabeça aos pés, relaxando o corpo todo. Toca o celular. Desliga o chuveiro e verifica a chamada. Não atende. Termina o banho. Bebe café, verifica os emails e as notificações das redes sociais. Reenvia o texto da reunião de orientação, que não havia chegado para alguém do grupo de pesquisa; confirma presença em um evento de arte; curte a foto de uma artista no Facebook. Calça as botas e sai. Lá fora, as ruas estão cheias de corpos que andam com pressa e carregam bolsas, mochilas, pastas, celulares. O camelô grita, o guarda de trânsito apita, o morador de rua pede dinheiro, o motorista do ônibus buzina, enquanto o trânsito segue lentamente. Com uma leve dor de cabeça, por causa da parafernália de sons na rua, o corpo, enfim, chega ao centro, dez minutos atrasado em relação ao horário previsto para as performances do coletivo "Perpendicular Invisível" começarem naquela fria manhã de junho. (Trecho Manual das (Ina)propriações de uma cartografia/junho de 2016).

Práxis Educativa, Ponta Grossa, v. 13, n. 3, p. 1003-1024, set./dez. 2018 Disponível em: < http://www.revistas2.uepg.br/index.php/praxiseducativa> 
Saia para rua depois de acenar, como faz todos os dias, para o porteiro. Escolha o caminho da esquerda [nunca vire para a direita!] e não se intimide com o vento congelante, que vem do noroeste da avenida e ameaça paralisar seu corpo. Esfregue as mãos, aqueça o rosto e, com os olhos levemente cerrados, se incline para vencer a resistência afiada do vento. Ande cerca de cinquenta metros. Pare no sinal e espere os carros passarem. Cruze os braços e proteja o peito, enquanto imagina de onde vem tanto frio, já que nas últimas décadas, em Belo Horizonte, o inverno quase nunca dá "o ar da graça". Aperte novamente as mãos no rosto buscando alívio. Reinicie a caminhada e, pare na esquina, para esperar o ônibus. Reconheça o perfume doce da senhora sentada ao seu lado, que provocará uma sequência de cinco espirros em você. Reze para o ônibus não demorar e, assim que chegar, suba com cuidado os sete degraus para não tropeçar. Olhe ao redor e localize aquele "lugar vazio". Ninguém senta com ninguém em um ônibus, desde que existam lugares disponíveis. Não! Não abra a bolsa, não pegue o livro! Isso, guarde-o! Coloque os fones de ouvido, faça como "todo mundo" e plugue-o no celular. Acompanhe a música mentalmente, não, não cante! Faça "cara de paisagem" e vamos em frente. Isso! Desça na Avenida Santos Dumont. Siga em direção ao viaduto Santa Tereza. Olhe ligeiramente ao redor e observe como quase todas as pessoas são cinzentas e apressadas. Observe o corpo magro do hippie vendendo artesanato na esquina, seus dedos ossudos e cheios de anéis e, por favor, não pare para conversar dessa vez. Lembre-se, você tem um compromisso de pesquisa! Volte a olhar para frente. Desvie com cuidado do corpo adormecido e, anestesiado pela cachaça, do morador de rua e se vier àquela vontade de chorar, chore! Se não acontecer, caso sinta que já tenha derramado todas as lágrimas possíveis ante a temerosa situação do seu País-Pós-Golpe, continue andando. Veja que o viaduto já está há uns trinta metros de distância e Ed Marte, em breve, iniciará suas performances pelas ruas do baixo centro. Sinta que um raio de sol desponta entre as nuvens atrás do Parque Municipal anunciando que a tarde vai esquentar. Pare! Olhe! Diminua a velocidade! Um Currículo DESVIANTE e desVIADO lhe aguarda logo à frente! (Trecho Manual das (Ina)propriações de uma cartografia/julho de 2017).

Os trechos do diário de campo aparecem aqui como "pedaços" de um diagrama maior das "forças sensoriais" que se apoderam dos corpos das pesquisadoras no território da cartografia. Tais afecções articulam-se com a compreensão de que, apesar de existir um caos primitivo do corpo, que nos acompanha por toda a vida, porque somos um corpo, adulto, educado e fechado, nossas fusões sensoriais tornam-se limitadas, inibidas, repetidas. Apenas conseguimos expressar o que Brian Massumi (2016) denomina artisticidade da experiência (MASSUMI, 2016) em momentos especiais, quando nos encontramos com acontecimentos que desterritorializam nossas sensações, como os encontros com certas obras de arte.

Nos dois trechos do diário, o corpo de uma pesquisadora agencia-se a outros corpos no território urbano. Corpos cinzentos e apressados que se mostram capturados em uma espécie de letargia. Esse corpo-fechado, quase que envolvido por uma carapaça invisível, realiza as tarefas do dia a dia com movimentos que lembram uma automação. Temos aqui uma inversão em relação ao corpo de uma criança que caminha por um território cartografando o novo, como no caso do pequeno Hans, que Deleuze e Guattari utilizam para explicar o conceito de "mapas" (DELEUZE; GUATTARI, 1997, p. 10).

O corpo-aberto-e-em-trânsito da criança encontra-se em relação inversa ao corpofechado do adulto, já que a criança é totalmente possuída pelo movimento. O corpo do bebê, por exemplo, é um caos de trancos e barrancos. Brian Massumi (2016) afirma que nossa vida se inicia corporalmente em meio a "um mar de intensidades", de "experiências multissensoriais". Contudo, aos poucos, "aos solavancos da repetição", vamos "cortando o movimento" em um "continuum" de experiências sensório-motoras. Assim, "cristalizam-se os objetos" e "o espaço vem à tona", até que, finalmente, "saímos do movimento", e somos "capturados pela repetição da variação" (MASSUMI, 2016, p. 14). 
Entretanto, o encontro com os signos da arte pode contribuir para reverter essa "inibição sensorial" no movimento, e fazer "variar as intensidades geológicas que dão forma às experiências" (MASSUMI, 2016, p. 11). A arte pode, sim, ser uma prática, experimental, afirmativa e extratora de forças. Ela pode criar um cenário de experiências que desencadeiam "novos picos de percepção" e fazem com que o corpo volte a expressar "a multiplicidade viva e movente que somos" (MASSUMI, 2016, p. 20). Ela pode produzir "desenvelopamentos" em nossa capacidade de acionar os devires:

São quase 19 horas. João, Gabriel ${ }^{13}$ e eu estamos na fila aguardando a distribuição de ingressos para a oficina-espetáculo do grupo Uzyna-Uzona, de Zé Celso Martinez. A oficina giraria em torno da vida e obra de Antonin Artaud. Estava marcada para acontecer à meia-noite dentro da programação da "Virada Cultural" programada para acontecer em Belo Horizonte, naquele mês de junho de 2016. Estou nervosa porque "Ed Marte", artista cujas performances me propus a cartografar, a esta hora deve estar performando pelas ruas do baixo centro da cidade. Afinal, sua ação artística estava marcada para acontecer justamente naquele horário em que nossos corpos se encontravam parados, congelados, naquela fila enorme. A performance Réquiem para uma Noiva deveria estar acontecendo, há uns três quilômetros dali, no "Viaduto Santa Tereza", um equipamento urbano usado como plataforma para várias subversões artísticas e políticas da cidade; palco de muitas ações de Ed Marte. Mas, se não der tempo? E se chegarmos tarde demais e a ação já tiver acabado? Aflijo-me. Afinal, aquele seria o meu primeiro encontro (cartográfico) com Ed Marte como pesquisadora, já que havíamos nos encontrado algumas vezes, antes de começar a cartografia. De repente, nossos ouvidos são atravessados por uma melodia estranha, melancólica e misteriosa. Dobrando a esquina, vemos um vulto branco, fantasmagórico, deslizando em nossa direção. O lusco-fusco daquele ser telúrico, disforme e espectral avançava cada vez mais. Mas, àquela distância, não era ainda perceptível aos nossos sentidos. Não sei porque meu coração começou a bater como se fosse saltar pela minha boca, numa disritmia tectônica. Enquanto isso, a imagem ganhava os contornos de um corpo vivo e não o de um fantasma, como parecia. Um corpo de uma noiva surgia. Não! Era o corpo de um homem vestido de noiva com uma barba reluzente e prateada contrastando com o tom virginal que nos provoca o véu e a grinalda! Era um "homem-noiva" que tocava um acordeom marrom-dourado debaixo da luz opaca e fria que descia da lua e compunha aquela espécie de quadro em movimento de Francis Bacon, numa mistura estranha de peles, pelos e tecidos. Depois disso, vieram os tremores, talvez por adivinhar o que estava acontecendo... "Intensidade" deve ser esse frio na espinha, essa vibração inexprimível, essa aceleração de partículas. Enquanto a vibração estranha, produzida pelo meu encontro com aquela Noiva Espectral, já havia se apoderado do meu corpo, que se dissolvia no chão, meus amigos não conseguiam conter o riso de espanto e alegria, enquanto me seguravam pelos braços e em tom de pilheria afirmavam: "só mesmo uma bruxa cartógrafa para atrair o 'objeto de pesquisa'14 no meio desta multidão sem rosto. (Trecho do Manual das (Ina)propriações de uma cartografia/outubro de 2017).

Nesse trecho do diário, temos uma das cartógrafas da pesquisa aqui em foco e seus amigos em uma fila, esperando a vez de adquirirem bilhetes para o teatro, enquanto, na cidade, muitas coisas ocorriam por causa da "Virada Cultural", um evento que prometia aos/às habitantes de Belo Horizonte 24 horas de atividades artísticas, culturais e shows espalhados por diversos pontos da capital mineira. A pesquisadora estava apreensiva, com medo de não conseguir chegar a tempo de acompanhar a ação de Ed Marte, que seria cartografada naquela noite. Então, uma espécie de aparição lhe arranca de si mesma e do território vivido. Ela experimenta o que Massumi

\footnotetext{
${ }^{13}$ Dois colegas do Grupo de Pesquisa que fizeram companhia a cartógrafa naquele dia.

${ }^{14}$ A alusão, nesse trecho, de que Ed Marte seja nosso "objeto de pesquisa" não procede, uma vez que o objetivo da nossa cartografia é mapear os encontros disparados por suas performances, não tendo como foco a pessoa que as realiza.
}

Práxis Educativa, Ponta Grossa, v. 13, n. 3, p. 1003-1024, set./dez. 2018 Disponível em: <http://www.revistas2.uepg.br/index.php/praxiseducativa $>$ 
(2016) denomina de "artisticidade da experiência" ao se deparar com a performance: "Réquiem para uma Noiva ${ }^{15 "}$ " de Ed Marte.

Segundo Deleuze (2007), o objeto de um encontro que nos atravessa na arte, o "signo artístico", é um ser da "sensibilidade" que "só pode ser sentido" e analisado pela "lógica das sensações" (DELEUZE, 2007, p. 72). Cartografar também é misturar-se com a emissão de signos de um território; é deixar-se inundar pelas intensidades que o agitam. É estar preparada para os imprevistos e os acidentes ocorridos. Isso significa criar para si um corpo aberto e em trânsito (virtual e intensivo) no território pesquisado. Tal corpo é criado e se efetua de modo alternativo ao corpo orgânico. O corpo virtual do/a cartógrafo/a não surge dos encontros previstos e previsíveis que ocorrem no território, mas dos "acontecimentos" que desterritorializam e arrancam o/a pesquisador/a desse território. Afinal, são nesses momentos inesperados, surpreendentes e fugazes que as singularidades de uma pesquisa saltam, acelerando as partículas que compõem a potência de pensar, de performar e de responder aos signos que capturam o/a cartógrafo/a no território pesquisado.

\section{Cartografar-Acionando o riso}

O exemplo de um signo que nos mobilizou no entre, quer dizer, no meio da cartografia foi o riso. O "riso", algo bastante sutil, mas, ao mesmo tempo, uma expressão muito perceptível nos "afectos", esteve presente em todas as performances e derivas realizadas por Ed Marte que cartografamos no Currículo da cidade com a arte. Era algo vívido, que chamava nossa atenção, mas também era escorregadio, gerava um "ponto de contração" no movimento de cartografarmos os encontros que aconteciam entre o corpo estranho da artista queer e seu público.

O riso intrigava-nos. Ele produzia uma inquietude que, vez ou outra, nos arrancava do território produzindo um "intervalo" ou um "corte" em nosso movimento. Sentíamos que era difícil dar uma "materialidade" ou tornar o riso algo cognoscível. Entretanto, sentíamos também que o riso merecia uma demorada atenção em nossa cartografia.

Sentimos, então, a necessidade de perseguir uma linha do riso que pudesse, com e entre o próprio ato de esboçar um riso, nos ajudar a compreendê-lo. Mergulhamos no riso; o riso em nós evocava uma espécie de "afecto" de "atitude valorativa"; no caso, uma "valoração nobre" por "manifestar um aumento de forças". Para Leite (2016), o riso é uma manifestação do "excesso de forças", efeito da "soberania ante o sentido das formas e objetos", visto que não há "objetos risíveis", não existe uma essência no riso. O riso é o "efeito de uma disposição afirmativa da vida" (LEITE, 2016, p. 20).

Não conseguíamos nos desviar do riso, pois ele estava sempre conosco, desafiando nosso entendimento; se fazendo ouvir, ver e sentir em meio às performances que íamos cartografando. Contudo, o riso fazia-se presente, também, nas reuniões de orientação, quando relatávamos alguns de nossos episódios. Ele podia ser sentido no rosto das colegas quando lhes mostrávamos trechos do diário, fotos das performances ou quando lhes contávamos sobre a relação que construíamos com Ed Marte. Aliás, o riso é a marca registrada de nosso grupo de pesquisa, juntamente às guloseimas que sempre dividimos entre "um parecer" e outro. Pode-se dizer que fazemos pesquisas que nos desafiam, mas também que, nos enchem de alegria, que aumentam nossas forças. Por tudo isso, resolvemos investir na linha do riso, tomando-o não somente como

15 "Na performance 'Réquiem para uma Noiva', a artista aborda as questões de gênero, feminismo e o universo queer do homem mulher trans, as lutas políticas de empoderamento e reafirmação do corpo livre." Trecho da Programação Oficial da Virada Cultural de Belo Horizonte, disponível em: <http://mapaculturalbh.pbh.gov.br/evento/1209/>. Acesso em: 15 jul. 2018.

Práxis Educativa, Ponta Grossa, v. 13, n. 3, p. 1003-1024, set./dez. 2018 Disponível em: <http://www.revistas2.uepg.br/index.php/praxiseducativa> 
o efeito de um "afecto" inquietante, mas como um gesto de pesquisa, um procedimento que nos permitia conectar com aqueles/as que fazem parte da nossa investigação.

\section{O riso Queer}

Percebemos durante a cartografia que o riso era uma espécie de porta de entrada para que outros "afectos" fossem acionados. Parecia-nos que a primeira reação das pessoas ao verem Ed Marte pela primeira vez era esboçar algum tipo de sorriso. Nos instantes em que um sorriso era esboçado, parecia-nos que algo diferente acontecia com o corpo das pessoas na rua. Era como se o corpo delas se abrisse e a carapaça invisível se dissolvesse por alguns breves momentos. Sentíamos que havia algo de singular no riso estampado no rosto do público das performances queer. Tentávamos, a todo custo, reter esse riso. No entanto, de alguma forma, ele nos escapava. Talvez porque era algo muito sutil que demandava uma atenção mais minuciosa em relação às microsutilezas dos "afectos", disparados pelas Corpografias Queers que íamos recolhendo durante a cartografia.

Entendemos as performances cartografadas em nossa investigação como Corpografias Queers por provocarem tensionamentos em relação à maneira como homens e mulheres performam seus gêneros. Em nossa pesquisa, operamos com os seguintes conceitos: gênero, como mecanismo pelo qual as noções de masculino e feminino são produzidas e naturalizadas, mas que podem, também, ser desconstruídas e desnaturalizadas (BUTLER, 2014); sexualidade, como um dispositivo histórico atravessado por relações de poder (FOUCAULT, 2014); e corpografia, como sensações que surgem do agenciamento corpo-cidade promovendo, tanto quanto implicando, "processos interativos" e "geradores de sentidos" que surgem da relação entre o corpo e a cidade no território urbano (JACQUES, 2008).

Nesse sentido, o riso surge como um registro preponderante na corpografia queer analisada em nossa pesquisa, mas também uma espécie de procedimento, de gesto ou de efeito relevante em nosso ato de cartografar. Decidimos que o riso era mesmo um elemento singular; por isso, precisávamos cartografar o riso! Começamos indagando-nos sobre que espécie de riso era aquele. Inicialmente, pareceu-nos que não era um riso de escárnio, deboche e/ou desprezo, conforme íamos apurando nos registros que dispúnhamos nos arquivos da cartografia. Pode ser que, vez ou outra, algum tipo de deboche tenha ocorrido. Todavia, se ocorreu, foi contido, não perceptível e não captado por nossas fotografias ou outros registros. $\mathrm{Na}$ grande maioria das cenas vistas, sentidas e captadas, era um outro tipo de riso que predominava no rosto das pessoas. A sensação era a de que o inusitado da situação provocada pelo encontro com um corpomasculino-de-mulher causava muito mais espanto e curiosidade nas pessoas, do que repulsa. No entanto, o riso continuava lá nos intrigando. Estaria aquele riso relacionado mesmo ao deboche e, por alguma razão, à falta de foco da cartógrafa, por exemplo, por não estar conseguindo relacionar? Ou aquele riso era mesmo mais próximo da alegria, de algo que, mesmo instantâneo, pode acionar uma potência nas ruas da cidade?

Ao depararmo-nos com o livro O valor do riso, da escritora Virgínia Woolf, estabelecemos uma conexão com algo que nos inquietava na cartografia. Woolf (2014) comenta que o "espírito de solenidade", em nossa época, substituiu o papel outrora ocupado pela tragédia na civilização grega. Diz a autora que, se esse "espírito de solenidade" tivesse um gênero, "ele seria masculino". Afinal, a comédia é "sensual, satírica, das graças e das musas". Diz, ainda, que até o riso puro das crianças "anda em descrédito" nos nossos dias, e o que presenciamos é sempre um "riso frívolo", que, segundo a autora, foi sendo "esvaziado de emoção". O riso "é o único som que nenhum animal pode produzir" (WOOLF, 2014, p. 34). "É a expressão do espírito cômico que existe

Práxis Educativa, Ponta Grossa, v. 13, n. 3, p. 1003-1024, set./dez. 2018 Disponível em: <http://www.revistas2.uepg.br/index.php/praxiseducativa $>$ 
dentro de cada um de nós". Quando nos esquecemos do riso, perdemos, segundo Woolf (2014), nosso "senso de realidade" (WOOLF, 2014, p. 34).

A humanidade preferiu seguir o caminho do "culto à solenidade" e do "espírito grave". Não "conseguimos tirar da cabeça" a crença de que "há sempre algo de virtuoso nas lágrimas" e na seriedade (WOOLF, 2014, p. 39), que é um atributo ou "afecto", segundo Woolf (2014), ligado ao masculino e que, algumas vezes, se transforma em uma postura irônica e descortês do deboche. Em relação à alegria que tensiona esse "espírito grave", Nietzsche também se colocou de forma contestadora, dizendo que "[...] se nada mais do presente existir no futuro, que justamente a nossa risada tenha um futuro" (NIETZSCHE, 2005, p. 223) ou, ainda, "[...] esta coroa de rosas é a coroa de quem ri: fui eu que a coloquei sobre minha cabeça, fui eu que canonizei meu riso" (NIETZSCHE, 2011, p. 18). Assim também pensa Isabelle Stengers ao afirmar: "[...] não acredito em uma ciência que não ri” (STENGERS, 2002, p. 29). Por isso, a autora está sempre em busca de outros modos de fazer ciência; uma maneira que ela chama de mais feminina, porque não dizer mais "alegre" de produzir conhecimento.

O tema do riso inquietou a Filosofia levando Henri Bergson, por exemplo, a dedicar um de seus ensaios inteiramente a esse tema. Em um texto de 1899, O Riso, Bergson (2001) diz que a comicidade seria a expressão capaz de nos lembrar que "o automatismo do corpo e da linguagem" correm em paralelo a uma "vida movente e dinâmica" (BERGSON, 2001, p. 240). Tal como a inteligência e a linguagem, Bergson (2001) entende a comicidade e, por extensão, o riso como algo vivo, "expressão tipicamente humana" (BERGSON, 2001, p. 240). O ser do riso, para Bergson, é a "sociabilidade". O filósofo argumenta que o riso produz ecos e que se faz em grupo, pois é preciso o encontro com "o outro" para que haja o riso. Para Bergson (2001), é preciso rir dos automatismos que nos constrangem, pois o riso permite-nos desmistificar a seriedade da vida. O riso seria, portanto, "um modo de entendimento" (BERGSON, 2001, p. 166), um tipo de inteligência.

Estirando um pouco mais a linha do riso no diagrama que traçávamos na cartografia, conectamos o riso ao queer. Uma das principais características do queer é justamente subverter e transgredir índices de expressão heteronormativos; transformando, por exemplo, os insultos recebidos em linhas de afirmação da vida, incorporando os insultos, mas subvertendo-os a sua lógica. Foi isso o que aconteceu com o uso do próprio termo "queer", objeto de uma "desterritorialização" no próprio sentido da palavra queer.

A linha que cruzamos entre o riso e o queer nos colocava cada vez mais próximas do movimento de transgressão da lógica heteronormativa; o que talvez nos autorizasse a pensar que as pessoas queer, como é o caso de Ed Marte, acionam uma ética, pautada em uma estética, que, ao disparar certos "maneirismos", ou seja, preferir um tom hiperbólico, exagerado e escrachado próprio do queer para saturar, esgotar as normas. Rir das normas é, portanto, uma maneira de transformar o riso em resistência, é um ato político "molecular" - como na estética camp (SONTAG, 1987), ao adotar "o deboche" como um modo de vida. Faz parte de uma atitude queer ser, sim, exibicionista, chamar a atenção e, principalmente, chocar, como forma de fazer micropolítica com o corpo.

Butler (2003) aproxima-se desse aspecto quando afirma que "rir de categorias sérias é indispensável” (BUTLER, 2003, p. 11). Preciado (2014) também aciona uma espécie de riso queer ao trazer, para o centro de suas narrativas, o dildo, personagem estético-conceitual, criado em seu "Manifesto Contrassexual", ao afirmar que "o insulto" se transforma em "elogio" para corpos que não são normais, mas, sim, "corpos-anômalos", que dão origem a novas "multidões queer". Afirma, ainda, que "a estética" e "a moda" contemporâneas tornaram-se "fluídas demais" e que "os corpos modificam antigas lógicas de prazer" e exibem agora "a centralidade das partes e de

Práxis Educativa, Ponta Grossa, v. 13, n. 3, p. 1003-1024, set./dez. 2018 Disponível em: <http://www.revistas2.uepg.br/index.php/praxiseducativa> 
órgãos antes menosprezados" (PRECIADO, 2014, p. 27). Estaria o mundo tornando-se um lugar muito mais queer do que poderia supor a nossa vã filosofia? Nesse cenário, rir, quer dizer, rir de nós mesmas, do que existe de ridículo e estranho em cada um, cada uma de nós, pode ser a condição necessária para fazer de nossos corpos uma máquina de guerra ${ }^{16}$.

Sim, o riso é de fato um importante procedimento das cartografias curriculares que fazemos. E, nesse processo, descobrimos que estamos bem acompanhadas, já que filósofos/as com os/as quais trabalhamos, autoras de literatura que nos inspira e pesquisadoras queer importantes que nos ajudam a interrogar os saberes existentes, de diferentes modos, chamaram atenção para a força do riso. Então, o riso ganhou destaque em nossas cartografias porque ele é potente; é um destruidor de formas; é um acionador de forças; um conector e agenciador importante para as investigações cartográficas de currículos que realizamos.

\section{Cartógrafas que riem de si mesmas}

Como a questão do riso queer tornou-se um signo importante em nossa cartografia, acabamos trans-in-corporando o riso como um procedimento importante em nossa investigação. Ao lançarmos mão do riso queer como um extrator de forças no território da cartografia, nós o assumimos como um gesto de pesquisa. Tal estratégia metodológica age sobre o corpo que realiza as cartografias, sendo de fundamental importância na criação de "entradas" e "saídas" em um território de pesquisa. Ao sorrirmos, acionamos uma afirmação da vida, vida e pesquisa se misturam e podem juntas dançar e sorrir e responder com uma corpografia mais afirmativa ao mau humor e à violência das pessoas que não suportam as diferenças, que não conseguem compreendê-las e nem compor com elas. O riso queer pode sim criar um movimento de abertura, uma ebulição, uma transmutação daquilo que somos (ou nos tornamos) em uma cartografia. Não se trata de um riso utópico, ou de revolução que se descortinará algum dia. Trata-se, apenas, de um sorriso, uma pirueta, uma dança, movimentos, encontros, entradas e saídas que se fazem presentes em qualquer território de pesquisa, desde que uma vontade afirmativa de não separar a vida da pesquisa entre em ação.

Por tudo isso, tratamos o riso queer como um importante vetor de abertura nos corpos, uma linha de fuga, que produz importantes desterritorializações de gênero no currículo da cidade com a arte. Seguimos com a hipótese de que o "riso queer" pode, sim, ser colocado na linha dos "afectos" que contribuem para ultrapassar a seriedade de uma vida acinzentada, apressada e letárgica, aumentando a potência de existir em uma cidade. Tomar as Corpografias Queer como máquinas de guerra, como resistência, pode ajudar-nos na batalha que travamos contra as formas e entre as forças para que corpos dissidentes possam caminhar e compor e sorrir e performar e dançar e viver o currículo da cidade com a arte de maneiras singulares.

\section{Concluir ou convidar para outros com-passos?}

Neste artigo, propusemo-nos a mostrar como o cartografar-caminhar, cartografarcompor e cartografar-rir podem ser utilizados como procedimentos metodológicos da pesquisa cartográfica em currículos ao movimentarem um combate-contra as formas e um combate-entre as forças a fim de criar "outros possíveis" nas pesquisas em educação, na mesma linha do que

\footnotetext{
16 "Somos máquinas desejantes"; "máquinas acopladas a outras máquinas, máquinas produzindo conexões, máquinas passando fluxos"; "tudo em nós cria, faz, corta, torce, processa, produz"; "nosso corpo é uma usina"; "uma máquina": é assim que Deleuze e Guattari definem, no "Antiédipo", "o ser humano", como uma "máquina de guerra". (DELEUZE; GUATTARI, 2010, p. 74).
}

Práxis Educativa, Ponta Grossa, v. 13, n. 3, p. 1003-1024, set./dez. 2018 Disponível em: <http://www.revistas2.uepg.br/index.php/praxiseducativa> 
vêm fazendo Paraíso (2010, 2015) e Paraíso e Caldeira (2018) em suas pesquisas-experimentação, que Paraíso (2015) chama de "Currículos e possibilidades". Nossas experiências cartográficas, de modo diferente dos trabalhos de Paraíso, dão-se no espaço público das ruas de Belo Horizonte, em meio às intempéries do tempo, do trânsito, do fluxo de pedestres, das buzinas dos carros, onde caminhamos com uma artista queer e nômade pelas ruas. Desse modo, também as cartógrafas se tornam nômades, na medida em que vão deslizando entre os espaços "lisos" e "estriados" (DELEUZE; GUATTARI, 2000), experimentados na prática investigativa. Ao "nomadizarem" pela cidade, as cartógrafas criam aberturas em suas pesquisas e em seus próprios corpos-em-trânsito. "Aberturas" que podem ser entendidas ao modo de uma dança, compassos de uma street dance que deixamos aqui para quem quiser se inspirar, (des)manchar, acrescentar, modificar; enfim, inventar o seu próprio modo de dançar:

\section{Com-passos para criar outros caminhos de pesquisa}

1- Nunca se sabe de antemão que caminhos serão traçados em uma cartografia; por isso, é interessante se munir de uma boa dose de incertitude antes de abrir a porta e sair para a rua.

2- A cartógrafa atua diretamente sobre um território cartografado, por isso deve estar sempre atenta aos efeitos que sua presença evoca no território.

3- Para Cartografar um território é necessário experimentar, experimentar, experimentar e ver/sentir no que isso pode dar.

4- Fazer Cartografia significa abrir-se e permanecer aberta às forças dos encontros.

5- Uma Cartografia é sempre inter e transdisciplinar, já que os saberes isolados de cada campo (Filosofia, Currículo, Geografia, Ciência e Arte) são insuficientes para dar conta da complexidade do objeto cartografado.

6- A Cartografia é um estudo geofilosófico, pois sempre envolve um território qualquer, seja ele: político, sentimental, ético, estético e/ou existencial.

7- Fazemos Cartografia para encontrar singularidades, mas não perdemos de vista o que um território tem de comum, de coletivo.

8- A cartografia está aberta ao disponível, imprevisível e improvável e imponderável e...

9- A cartógrafa está sempre em movimento, ziguezagueando; nunca caminhando em linhas retas e nem circulares.

10- A cartógrafa é uma artista, uma compositora: faz do seu percurso, uma dança, uma música; enfim, uma obra de arte.

11- A Cartografia é uma prática investigativa que ganha contornos no processo e faz uma operação sobre o mundo.

12- Então, já que é assim, invente os seus próprios com-passos, mas não se esqueça do riso. Sim, o riso pode abrir portas na cartografia, no currículo e na vida! (Trecho de "Linhas de experimentação do diário da cartografia", setembro de 2017).

\section{Referências}

BENJAMIN, W. Charles Baudelaire: um lírico no auge do capitalismo. São Paulo: Brasiliense, 1994.

BENJAMIN, W. Rua de sentido único e infância em Berlim por volta de 1900. Lisboa: Relógio D’água, 1992.

BERGSON, H. O Riso - ensaio sobre a significação da comicidade. São Paulo: Martins Fontes, 2001.

BLANCHOT, M. A parte do fogo. Rio de Janeiro: Rocco, 1997. 
BONAFÉ, J. La ciudad en el curriculum y el curriculum en la ciudad. In: GIMENO, J. Saberes e incertumbres sobre el curriculum. Madrid: Morata, 2010. p. 527-547.

BUTLER, J. Problemas de gênero: feminismo e subversão da identidade. Rio de Janeiro: Record, 2003.

BUTLER, J. Regulações de gênero. Cadernos Pagu, Campinas, n. 42, p. 249-274, 2014.

CARERI, F. Walkscapes: o caminhar como prática estética. São Paulo: Editora G, 2013.

DELEUZE, G. A imagem-movimento. São Paulo: Brasiliense, 1985.

DELEUZE, G. Conversações. Tradução Peter Pál Pelbart. São Paulo: 34, 1992.

DELEUZE, G. O atual e o virtual. In: ALLIEZ, É. Deleuze: filosofia virtual. São Paulo: 34, 1996. p. 47-57.

DELEUZE, G. Foucault. São Paulo: Brasiliense, 2005.

DELEUZE, G. Francis Bacon. A lógica da sensação. Rio de Janeiro: Zahar, 2007.

DELEUZE, G. Crítica e clínica. Tradução Peter Pál Pelbart. São Paulo: 34, 1997.

DELEUZE, G. A ilha deserta. Tradução Luiz Orlandi. São Paulo: Iluminuras, 2006.

DELEUZE, G. Espinosa e o problema da expressão. São Paulo: 34, 2017.

DELEUZE, G.; GUATTARI, F. Mil Platôs. Volume 1. São Paulo: 34, 1995a.

DELEUZE, G.; GUATTARI, F. Mil Platôs. Volume 2. São Paulo: 34, 1995b.

DELEUZE, G.; GUATTARI, F. Mil Platôs. Volume 4. São Paulo: 34, 1997.

DELEUZE, G.; GUATTARI, F. Mil Platôs. Volume 5. São Paulo: 34, 2000.

DELEUZE, G.; GUATTARI, F. O que é Filosofia? São Paulo: 34, 2007.

DELEUZE, G.; GUATTTARI, F. O Anti-Édipo. São Paulo: 34, 2010.

FOUCAULT, M. O uso dos prazeres e as técnicas de si. In: FOUCAULT, M. Ditos e Escritos V: Ética, política e sexualidade. Rio de Janeiro: Forense Universitária, 2004. p. 198-199.

FOUCAULT, M. O corpo utópico, as heterotopias. São Paulo: N-1 Edições, 2013.

FOUCAULT, M. Ditos e Escritos IX: genealogia da ética, subjetividade e sexualidade. Rio de Janeiro: Forense Universitária, 2014. p. 118-141.

GRÓS, F. Caminhar, uma filosofia. São Paulo: Realizações, 2010. 
INGOLD, T. Estar vivo: ensaios sobre o movimento, conhecimento e descrição. Petrópolis: Vozes, 2015.

JACQUES, P. B. Apologia da deriva: escritos situacionistas sobre a cidade. Rio de Janeiro: Casa da Palavra, 2003.

JACQUES, P. B. Corpografias urbanas. Vitruvius [online], ano 8, 2008. Disponível em: <http://www.vitruvius.com.br/revistas/read/arquitextos/08.093/165>. Acesso em: 15 jul. 2018.

KASTRUP, V.; ESCÓSSIA, L.; PASSOS, E. Pistas do método da cartografia. Porto Alegre: Sulina, 2009.

LARROSA, J. Notas sobre a experiência e o saber da experiência. Revista Brasileira de Educação, Rio de Janeiro, n. 19, p. 20-28, jan./abr. 2002.

LEITE, T. R. de M. Nietzsche e o riso. 2016. 205 f. Dissertação (Mestrado em Filosofia) Universidade de São Paulo, São Paulo, 2016.

MASSCHELEIN, J.; SIMONS, M. Em defesa da escola: uma questão pública. Belo Horizonte: Autêntica, 2014.

MASSUMI, B. A arte do corpo relacional: do espelho-tátil ao corpo virtual. Revista Galáxia, São Paulo, n. 31, p. 5-21, 2016.

HARDT, M.; NEGRI, A. Multidão. Rio de Janeiro: Record, 2005.

NIETZSCHE, F. Além do bem e do mal. São Paulo: Companhia das Letras, 2005.

NIETZSCHE, F. Assim falou Zaratustra. São Paulo: Companhia das Letras, 2011.

NIETZSCHE, F. Ecce Homo. Tradução Paulo César de Souza. São Paulo: Companhia das Letras, 1995.

PARAÍSO, M. A. Diferença no currículo. Cadernos de Pesquisa, São Paulo, v. 40, n. 140, p. 587-604, maio/ago. 2010.

PARAÍSO, M. Currículo-nômade: quando os devires fazem a diferença proliferar. In: COSTA, M. (Org.). Estudos culturais e educação. Canoas: Ulbra, 2015. p. 268-289.

PARAÍSO, M.; CALDEIRA, M. C. Pesquisas sobre currículos, gêneros e sexualidades. (Orgs.). Belo Horizonte: Mazza, 2018.

PELBART, P. A nau do tempo-rei: sete ensaios sobre o tempo da loucura. Rio de Janeiro: Imago, 1993.

PEREIRA, P. Corpo, sexo e subversão: reflexões sobre duas teóricas queer. Interface Comunicação, Saúde, Educação, v. 12, n. 26, p. 499-512, 1987. DOI: https://dx.doi.org/10.1590/S1414-32832008000300004 
PRECIADO, B. Manifesto contrassexual. São Paulo: N-1 Edições, 2014.

SANTOS, L. G. O intolerável + Escutas em transe. São Paulo: N-1 Edições, 2016. (Coleção Pandemia).

SONTAG, S. Notas sobre a estética camp. In: SONTAG, S. Contra a interpretação. São Paulo: L\&PM Editores, 1987. p. 318-337.

SPARGO, T. Foucault e a teoria queer, seguido de Ágape e êxtase: orientações pósseculares. Belo Horizonte: Autêntica, 2017.

STENGERS, I. A invenção das ciências modernas. São Paulo: 34, 2002.

WOOLF, V. O valor do riso. São Paulo: Cosac Naify, 2014.

Recebido em 11/05/2018

Versão corrigida recebida em 13/07/2018

Aceito em 15/07/2018

Publicado online 23/07/2018 